\title{
Insulin secretion after open-heart surgery with particular respect to pathogenesis of low cardiac output state
}

\author{
P. A. Majid, P. Ghosh, B. C. Pakrashi, M. Ionescu, J. R. W. Dykes, and \\ S. H. Taylor ${ }^{1}$ \\ From the Cardiovascular Unit and the Departments of Medicine, Thoracic Surgery, and \\ Chemical Pathology, University of Leeds, at the General Infirmary, Leeds
}

Insulin secretion tests, and measurements of systemic arterial free fatty acids, pyruvate, and lactate were carried out before operation in 6 patients undergoing open-heart surgery for valve replacement. The measurements were serially repeated after operation and the results were related to the clinical state of the patient. In patients developing the clinical picture of a low cardiac output state, the systemic arterial free fatty acid, lactate, and pyruvate levels were all greatly increased and the secretion of insulin severely suppressed. These variables gradually returned to their preoperative levels in parallel with improvement in the clinical state in each patient. The therapeutic implications of these findings are discussed in relation to the use of insulin in the postoperative management of patients undergoing open-heart operation.

The low cardiac output syndrome is a major hazard of the early postoperative period after open-heart surgery, and its onset is associated with a high mortality. Correction of hypovolaemia and the counteraction of depressed left ventricular function by inotropic agents and vasodilator drugs have greatly improved the outlook, but some patients still fail to respond adequately to these measures. The primary fault is one of pumping failure of the heart, and in this respect it is similar to the heart failure associated with naturally occurring disease. The pumping failure associated with cardiogenic shock after myocardial infarction and that associated with severe congestive heart failure have both been found to be accompanied by suppression of insulin secretion (Taylor et al., 1969; Sharma et al., 1970). The following investigation was, therefore, designed to measure the facility with which insulin was released in patients undergoing open-heart operations for valve replacement.

\section{Subjects and methods}

Clinical details Six patients undergoing openheart surgery for mitral or aortic valve replace-

Received 25 February 1970.

1 Requests for reprints should be addressed to $S$. $H$. Taylor, Department of Medicine, The General Infirmary, Leeds, LSI 3 EX. ment were studied. Their personal, clinical, surgical, and laboratory details are listed in Table $\mathrm{r}$. None was in congestive heart failure at the time of the preoperative studies, though all were severely incapacitated by breathlessness on exertion. Cases 2 and 6 were in sinus rhythm; the remainder were in atrial fibrillation. The chest radiographs and electrocardiographic findings were consistent with the clinical diagnoses and all patients were adjudged good surgical risks. Informed consent for the studies was obtained from all patients.

Design of investigation Measurements were made of the systemic arterial blood gas tensions, $p \mathrm{H}$, free fatty acids, lactate, pyruvate, and glucose immediately before an insulin secretion test was performed; these measurements were made on the day before operation, during the first 12 hours after operation (Day I), and on the 2nd, 5 th, 7 th, I4th, and 28th postoperative days. The insulin secretion test was based on the potency of intravenous tolbutamide to release preformed insulin from the beta cells of the pancreas (Seltzer, I962). The standardization, repeatability, and range of normal values of this test have been reported elsewhere (Saxton et al., 1970). After the control venous sample, I g. tolbutamide was injected intravenously over ro seconds. Further venous blood samples for the measurement of glucose and insulin were taken at $1,2,5,10,15,30$, and 60 minutes. None of the patients complained of or showed any side-effects after the injection. The results of the insulin secretion tests were compared 
TABLE I Clinical and laboratory details of patients studied

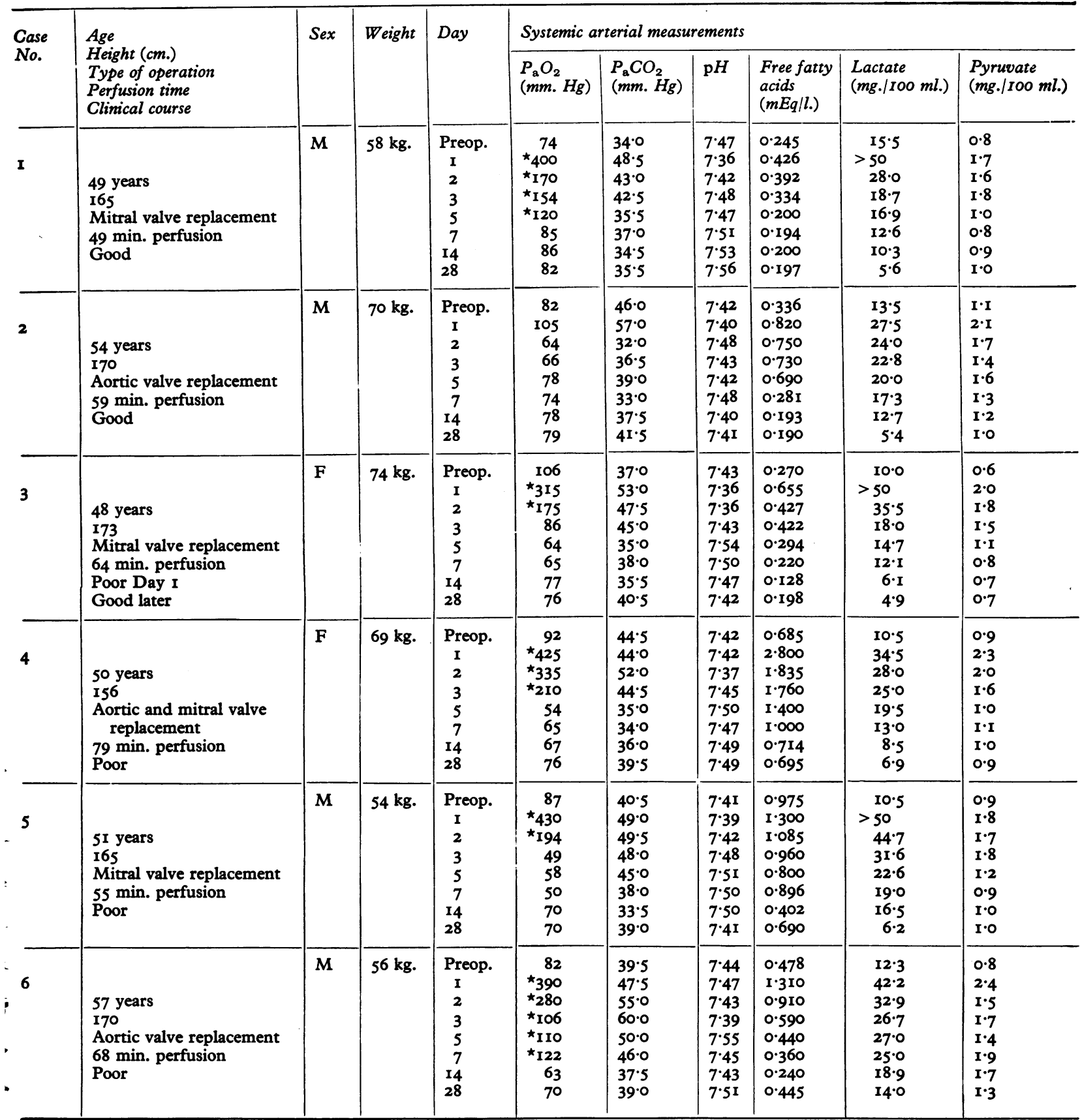

- On 100 per cent oxygen by face mask at $8 \mathrm{l}$./min.

$\hat{3}$

with those obtained from 12 normal male subjects aged $40-65$ years.

- The study was specifically designed not to interfere in any way with the routine postoperative treatment of the patient. All but one patient (Case 2) received oxygen by face mask for some days after operation (Table I). During the first 3

days after operation all patients routinely received intravenous glucose therapy which probably accounts in part for the very high values of blood glucose observed at this time. Except for the studies during the first 3 postoperative days the insulin secretion tests were carried out in the morning 3 hours after a light meal. 
TABLE 2 Results of insulin secretion test in patients undergoing open-heart operations

\begin{tabular}{|c|c|c|c|c|c|c|c|c|c|c|c|c|c|c|c|c|c|}
\hline \multirow{2}{*}{$\begin{array}{l}\text { Case } \\
\text { No. }\end{array}$} & \multirow{2}{*}{$\begin{array}{c}\text { Time } \\
(\min .)\end{array}$} & \multicolumn{2}{|c|}{ Preop. } & \multicolumn{2}{|c|}{ Day $I$} & \multicolumn{2}{|c|}{ Day 2} & \multicolumn{2}{|c|}{ Day 3} & \multicolumn{2}{|c|}{ Day 5} & \multicolumn{2}{|c|}{ Day 7} & \multicolumn{2}{|c|}{ Day I4 } & \multicolumn{2}{|c|}{ Day 28} \\
\hline & & Ins. * & Glu. & Ins. & Glu. & Ins. & Glu. & Ins. & Glu. & Ins. & Glu. & Ins. & Glu. & Ins. & Glu. & Ins. & Glu. \\
\hline I & $\begin{array}{r}\text { C } \\
1 \\
2 \\
5 \\
10 \\
15 \\
30 \\
60\end{array}$ & $\begin{array}{r}21 \\
97 \\
268 \\
267 \\
226 \\
218 \\
30 \\
30\end{array}$ & $\begin{array}{l}60 \\
58 \\
70 \\
60 \\
65 \\
56 \\
32 \\
30\end{array}$ & $\begin{array}{r}37 \\
184 \\
285 \\
264 \\
269 \\
184 \\
133 \\
116\end{array}$ & $\begin{array}{l}286 \\
295 \\
214 \\
264 \\
270 \\
306 \\
246 \\
144\end{array}$ & $\begin{array}{r}76 \\
179 \\
323 \\
413 \\
408 \\
392 \\
404 \\
193\end{array}$ & $\begin{array}{r}115 \\
104 \\
102 \\
104 \\
92 \\
88 \\
58 \\
52\end{array}$ & $\begin{array}{c}G o \\
51 \\
116 \\
227 \\
264 \\
274 \\
292 \\
266 \\
76\end{array}$ & $\begin{array}{l}d \text { clin } \\
186 \\
172 \\
164 \\
232 \\
186 \\
192 \\
176 \\
103\end{array}$ & $\begin{array}{l}\text { cal co } \\
237 \\
374 \\
537 \\
596 \\
609 \\
595 \\
541 \\
189\end{array}$ & $\begin{array}{r}r s e \\
\text { ro4 } \\
98 \\
100 \\
94 \\
90 \\
86 \\
66 \\
32\end{array}$ & $\begin{array}{r}109 \\
351 \\
514 \\
517 \\
486 \\
476 \\
213 \\
47\end{array}$ & $\begin{array}{l}72 \\
80 \\
83 \\
76 \\
69 \\
43 \\
40 \\
30\end{array}$ & $\begin{array}{r}138 \\
574 \\
581 \\
541 \\
493 \\
452 \\
115 \\
48\end{array}$ & $\begin{array}{l}80 \\
72 \\
69 \\
66 \\
54 \\
49 \\
30 \\
25\end{array}$ & $\begin{array}{r}63 \\
177 \\
368 \\
338 \\
282 \\
212 \\
89 \\
36\end{array}$ & $\begin{array}{l}89 \\
89 \\
90 \\
85 \\
75 \\
63 \\
50 \\
42\end{array}$ \\
\hline 2 & $\begin{array}{r}\text { C } \\
\text { I } \\
2 \\
5 \\
10 \\
15 \\
30 \\
60\end{array}$ & $\begin{array}{r}30 \\
313 \\
312 \\
311 \\
288 \\
278 \\
193 \\
70\end{array}$ & $\begin{array}{l}78 \\
75 \\
75 \\
73 \\
68 \\
63 \\
49 \\
47\end{array}$ & $\begin{array}{r}54 \\
188 \\
213 \\
223 \\
215 \\
235 \\
199 \\
190\end{array}$ & $\begin{array}{r}126 \\
113 \\
109 \\
101 \\
104 \\
98 \\
78 \\
62\end{array}$ & $\begin{array}{r}34 \\
225 \\
219 \\
211 \\
184 \\
166 \\
140 \\
63\end{array}$ & $\begin{array}{l}76 \\
73 \\
72 \\
74 \\
73 \\
70 \\
64 \\
46\end{array}$ & $\begin{array}{r}48 \\
217 \\
212 \\
230 \\
188 \\
203 \\
140 \\
86\end{array}$ & $\begin{array}{l}96 \\
94 \\
95 \\
94 \\
90 \\
80 \\
74 \\
70\end{array}$ & $\begin{array}{r}45 \\
287 \\
285 \\
197 \\
173 \\
144 \\
112 \\
36\end{array}$ & $\begin{array}{r}100 \\
98 \\
102 \\
103 \\
88 \\
83 \\
60 \\
45\end{array}$ & $\begin{array}{l}208 \\
390 \\
369 \\
334 \\
339 \\
325 \\
285 \\
266\end{array}$ & $\begin{array}{r}117 \\
117 \\
110 \\
107 \\
92 \\
86 \\
70 \\
66\end{array}$ & $\begin{array}{r}26 \\
276 \\
292 \\
221 \\
216 \\
183 \\
103 \\
48\end{array}$ & $\begin{array}{l}84 \\
78 \\
74 \\
72 \\
68 \\
62 \\
46 \\
44\end{array}$ & $\begin{array}{r}25 \\
251 \\
287 \\
180 \\
143 \\
157 \\
158 \\
28\end{array}$ & $\begin{array}{l}72 \\
72 \\
73 \\
70 \\
65 \\
58 \\
49 \\
38\end{array}$ \\
\hline 3 & $\begin{array}{r}\text { C } \\
\text { I } \\
2 \\
5 \\
10 \\
15 \\
30 \\
60\end{array}$ & $\begin{array}{l}103 \\
312 \\
324 \\
313 \\
275 \\
240 \\
198 \\
162\end{array}$ & $\begin{array}{l}63 \\
55 \\
59 \\
55 \\
50 \\
43 \\
33 \\
23\end{array}$ & $\begin{array}{l}46 \\
74 \\
88 \\
97 \\
74 \\
57 \\
53 \\
35\end{array}$ & $\begin{array}{l}196 \\
190 \\
215 \\
207 \\
203 \\
180 \\
186 \\
208\end{array}$ & $\begin{array}{l}163 \\
192 \\
180 \\
218 \\
217 \\
212 \\
214 \\
173\end{array}$ & $\begin{array}{l}128 \\
122 \\
120 \\
120 \\
115 \\
114 \\
112 \\
100\end{array}$ & $\begin{array}{l}174 \\
252 \\
284 \\
307 \\
332 \\
333 \\
333 \\
213\end{array}$ & $\begin{array}{r}106 \\
104 \\
101 \\
100 \\
98 \\
95 \\
85 \\
52\end{array}$ & $\begin{array}{r}37 \\
105 \\
141 \\
211 \\
302 \\
315 \\
328 \\
144\end{array}$ & $\begin{array}{l}81 \\
73 \\
78 \\
74 \\
73 \\
70 \\
63 \\
48\end{array}$ & $\begin{array}{l}351 \\
357 \\
437 \\
459 \\
457 \\
462 \\
432 \\
379\end{array}$ & $\begin{array}{l}62 \\
64 \\
58 \\
52 \\
56 \\
54 \\
49 \\
47\end{array}$ & $\begin{array}{r}59 \\
66 \\
142 \\
266 \\
262 \\
243 \\
217 \\
75\end{array}$ & $\begin{array}{l}80 \\
76 \\
78 \\
74 \\
75 \\
72 \\
60 \\
46\end{array}$ & $\begin{array}{l}176 \\
230 \\
309 \\
349 \\
365 \\
342 \\
305 \\
150\end{array}$ & $\begin{array}{l}88 \\
88 \\
89 \\
89 \\
87 \\
84 \\
70 \\
48\end{array}$ \\
\hline 4 & $\begin{array}{l}C \\
1 \\
2 \\
5 \\
10 \\
15 \\
30 \\
60\end{array}$ & $\begin{array}{r}52 \\
210 \\
220 \\
176 \\
141 \\
114 \\
107 \\
45\end{array}$ & $\begin{array}{l}80 \\
75 \\
75 \\
70 \\
63 \\
60 \\
52 \\
49\end{array}$ & $\begin{array}{l}26 \\
30 \\
32 \\
44 \\
44 \\
49 \\
46 \\
26\end{array}$ & $\begin{array}{l}216 \\
214 \\
184 \\
188 \\
176 \\
176 \\
180 \\
190\end{array}$ & $\begin{array}{r}83 \\
139 \\
181 \\
160 \\
160 \\
187 \\
158 \\
120\end{array}$ & $\begin{array}{r}100 \\
97 \\
90 \\
87 \\
85 \\
82 \\
73 \\
69\end{array}$ & $\begin{array}{r}P o \\
33 \\
66 \\
97 \\
103 \\
118 \\
132 \\
99 \\
59\end{array}$ & $\begin{array}{l}\text { clin } \\
68 \\
68 \\
68 \\
68 \\
65 \\
63 \\
58 \\
53\end{array}$ & $\begin{array}{l}23 \\
39 \\
52 \\
84 \\
89 \\
77 \\
71 \\
30\end{array}$ & $\begin{array}{l}s e \\
77 \\
77 \\
82 \\
80 \\
78 \\
76 \\
70 \\
68\end{array}$ & $\begin{array}{l}15 \\
67 \\
71 \\
71 \\
68 \\
95 \\
85 \\
58\end{array}$ & $\begin{array}{l}76 \\
81 \\
86 \\
86 \\
84 \\
81 \\
74 \\
69\end{array}$ & $\begin{array}{r}45 \\
173 \\
272 \\
172 \\
143 \\
110 \\
66 \\
40\end{array}$ & $\begin{array}{l}76 \\
80 \\
78 \\
72 \\
70 \\
66 \\
54 \\
44\end{array}$ & $\begin{array}{r}30 \\
175 \\
168 \\
115 \\
93 \\
86 \\
49 \\
28\end{array}$ & $\begin{array}{l}73 \\
72 \\
73 \\
71 \\
69 \\
64 \\
50 \\
40\end{array}$ \\
\hline 5 & $\begin{array}{r}\text { C } \\
\text { I } \\
2 \\
5 \\
10 \\
15 \\
30 \\
60\end{array}$ & $\begin{array}{r}24 \\
329 \\
362 \\
335 \\
267 \\
197 \\
118 \\
32\end{array}$ & $\begin{array}{l}89 \\
86 \\
92 \\
90 \\
88 \\
76 \\
56 \\
50\end{array}$ & $\begin{array}{l}26 \\
36 \\
57 \\
56 \\
46 \\
49 \\
64 \\
28\end{array}$ & $\begin{array}{l}175 \\
170 \\
165 \\
108 \\
160 \\
165 \\
172 \\
163\end{array}$ & $\begin{array}{l}160 \\
156 \\
155 \\
175 \\
170 \\
165 \\
163 \\
160\end{array}$ & $\begin{array}{r}105 \\
93 \\
96 \\
95 \\
95 \\
93 \\
92 \\
100\end{array}$ & $\begin{array}{l}156 \\
149 \\
181 \\
193 \\
192 \\
247 \\
265 \\
213\end{array}$ & $\begin{array}{r}128 \\
110 \\
110 \\
108 \\
103 \\
101 \\
95 \\
88\end{array}$ & $\begin{array}{r}42 \\
190 \\
280 \\
355 \\
353 \\
371 \\
313 \\
311\end{array}$ & $\begin{array}{l}98 \\
95 \\
94 \\
96 \\
94 \\
90 \\
82 \\
68\end{array}$ & $\begin{array}{r}48 \\
67 \\
176 \\
308 \\
288 \\
336 \\
151 \\
44\end{array}$ & $\begin{array}{l}92 \\
86 \\
88 \\
86 \\
86 \\
74 \\
63 \\
50\end{array}$ & $\begin{array}{r}50 \\
252 \\
458 \\
517 \\
509 \\
473 \\
380 \\
58\end{array}$ & $\begin{array}{r}100 \\
95 \\
98 \\
90 \\
86 \\
83 \\
56 \\
50\end{array}$ & $\begin{array}{r}34 \\
337 \\
440 \\
415 \\
464 \\
440 \\
340 \\
93\end{array}$ & $\begin{array}{l}66 \\
64 \\
63 \\
62 \\
60 \\
59 \\
46 \\
38\end{array}$ \\
\hline 6 & $\begin{array}{c}\text { C } \\
\text { I } \\
2 \\
5 \\
10 \\
15 \\
30 \\
60\end{array}$ & $\begin{array}{r}25 \\
294 \\
207 \\
225 \\
180 \\
195 \\
143 \\
57\end{array}$ & $\begin{array}{l}72 \\
68 \\
72 \\
66 \\
66 \\
60 \\
50 \\
34\end{array}$ & $\begin{array}{l}22 \\
21 \\
32 \\
47 \\
65 \\
71 \\
62 \\
71\end{array}$ & $\begin{array}{l}25 I \\
235 \\
242 \\
239 \\
237 \\
233 \\
229 \\
224\end{array}$ & $\begin{array}{r}61 \\
53 \\
97 \\
124 \\
120 \\
121 \\
111 \\
93\end{array}$ & $\begin{array}{r}110 \\
109 \\
108 \\
103 \\
93 \\
101 \\
107 \\
96\end{array}$ & $\begin{array}{l}4 \mathrm{I} \\
27 \\
37 \\
73 \\
77 \\
83 \\
90 \\
69\end{array}$ & $\begin{array}{l}108 \\
107 \\
115 \\
116 \\
103 \\
115 \\
116 \\
105\end{array}$ & $\begin{array}{r}54 \\
127 \\
200 \\
330 \\
268 \\
170 \\
163 \\
103\end{array}$ & $\begin{array}{r}120 \\
118 \\
118 \\
116 \\
110 \\
108 \\
96 \\
80\end{array}$ & $\begin{array}{r}24 \\
102 \\
110 \\
150 \\
155 \\
149 \\
112 \\
91\end{array}$ & $\begin{array}{l}98 \\
92 \\
92 \\
94 \\
92 \\
88 \\
80 \\
62\end{array}$ & $\begin{array}{l}109 \\
344 \\
411 \\
428 \\
392 \\
421 \\
366 \\
296\end{array}$ & $\begin{array}{r}134 \\
130 \\
120 \\
124 \\
106 \\
102 \\
96 \\
82\end{array}$ & $\begin{array}{l}149 \\
323 \\
396 \\
480 \\
364 \\
350 \\
253 \\
117\end{array}$ & $\begin{array}{r}133 \\
130 \\
125 \\
119 \\
114 \\
103 \\
90 \\
52\end{array}$ \\
\hline
\end{tabular}

* Plasma insulin ( $\mu$ unit $/ \mathrm{ml}$.).

† Blood glucose (mg./100 ml.).

Laboratory techniques Blood gas measurements were made by a polarographic technique, and $\mathrm{pH}$ was determined by a micro-electrode method. The polarographic measurements were made on a gas-calibrated direct reading instrument (Electronic Instruments Laboratories Ltd.); the standard deviation between duplicates for $\mathrm{P}_{\mathrm{a}} \mathrm{O}_{2}$,
$\mathrm{P}_{\mathrm{a}} \mathrm{CO}_{2}$, and $\mathrm{pH}$ were $0.63 \mathrm{~mm}$., $\mathrm{I} \cdot 35 \mathrm{~mm}$., and $0.0 \mathrm{r}$, respectively. Blood lactate was measured by the technique of Marbach and Weil (1967); the coefficient of variation at $13 \mathrm{mg}$. $/ 100 \mathrm{ml}$. was 7 per cent. Blood pyruvate was measured by the method of Gloster and Harris (1962); the coefficient of variation at $\mathrm{I} \mathrm{mg}$./ $100 \mathrm{ml}$. was Io per cent. 
Total free fatty acids were estimated colorimetrically by the method of Laurell and Tibbling (1967) after extraction by the method of Duncombe (I963); the coefficient of variation at $0.5 \mathrm{mEq} / \mathrm{l}$. was 7 per cent. The blood glucose concentration was estimated by an 'Autoanalyser' glucose oxidase technique (Morley, Marks, and Dawson, 1966); the coefficient of variation at $106 \mathrm{mg} . / 100$ ml. was 5 per cent. Immunoreactive insulin was measured by the double-antibody radioimmunoassay method of Hales and Randle (1963), employing the reagents and oxoid membrane filter supplied by the Radio Chemical Centre at Amersham. The standards were based on crystalline bovine insulin using a calibration range $0-500$ $\mu$ units $/ \mathrm{ml}$. The standard deviation of the assay method, calculated from the differences between 200 duplicate determinations in each of the concentration ranges 0-45, 50-99, 100-199, and greater than $200 \mu$ units/ml., was $\pm 3 \cdot 3, \pm 7 \cdot 4, \pm 9 \cdot 7$, and $\pm 12.3 \mu$ units $/ \mathrm{ml}$., respectively. All measurements were made in duplicate.

Measurements and calculations A quantitative measure of the 'total' insulin secretion was estimated by calculating the separate areas under the plasma curves for the first Io minutes and for the whole hour after the tolbutamide injection. Statistical analyses were based on orthodox methods (Fisher, 1944).

\section{- Results}

Studies before operation Before operation the systemic arterial blood gas tensions , and $p H$ were within the normal range in all 6 patients (Table $I$ ). The arterial free fatty acid level was within normal limits except in one patient (Case 2) in whom it was raised. The systemic arterial blood lactate was raised in one patient (Case I) before operation but was Twithin normal limits in the remainder. The arterial pyruvate level was raised in one patient (Case 2); in the remainder it was within normal limits. The resting values of arterial blood gas tensions, $p H$, free fatty acids, and dactate and pyruvate were consistent with the clinical and circulatory state of these patients. 7 The insulin secretion response after tolbutamide was within the normal range in all 6 patients (Fig. I and Table 2). The control blood glucose level was within the normal range in all 6 patients. The fall in blood glucose level during the 60 minutes after the injection of tolbutamide averaged 48 per cent (range 38-64\%) compared with a fall of 51 per cent in normal subjects, and reflects the normal output of insulin in all these patients

before operation.

Studies after operation Two patients (Cases I and 2) made excellent progress after operation, and at no time gave rise to concern.

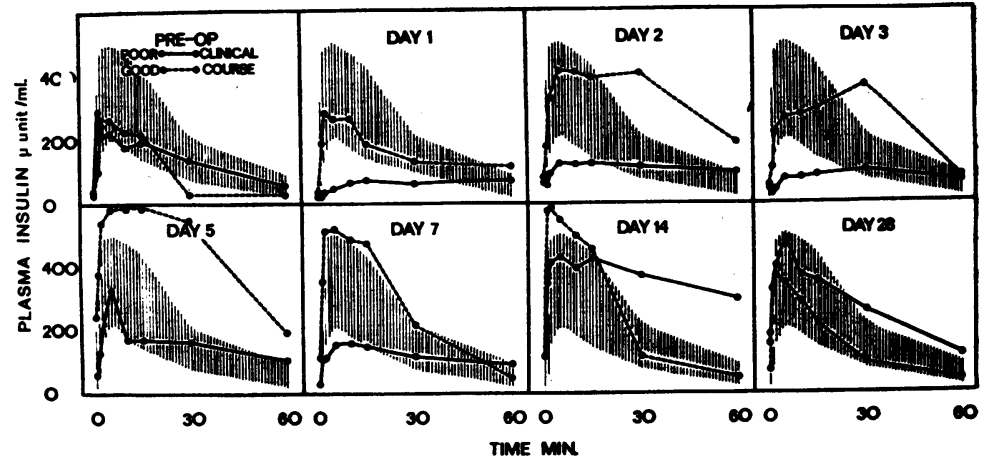

FIG. I Insulin secretion response to intravenous tolbutamide in two patients before and after open-heart operation. The range in 12 normal subjects (mean $\pm 2 S D$ ) is crosshatched.

One patient (Case 3) presented clinical signs of a low output state on Day I but thereafter made excellent clinical progress. The 3 remaining patients (Cases 4, 5, and 6) had a difficult and prolonged postoperative course and all 3 presented the clinical picture of the low cardiac output syndrome in the immediate postoperative period. Case 4 was seriously ill for more than a week. Case 5 was seriously ill for the first 48 hours after operation but then rapidly improved. Case 6 was seriously ill for 72 hours after operation before improvement began.

The systemic arterial blood gas tensions and $p \mathrm{H}$ showed no consistent changes during the postoperative period due to the routine treatment with oxygen by face mask and correction of any fall in systemic arterial $p \mathrm{H}$ with parenteral sodium bicarbonate. The systemic arterial free fatty acid, lactate, and pyruvate measurements all showed a consistent pattern of change after operation. There was a considerable increase in all three variables during the immediate postoperative period, with a gradual return to their original preoperative level during the succeeding 28 days. The extent of the changes in these three variables correlated well with the clinical state of these patients (Table I). The insulin secretion test likewise showed a close relation with the clinical state of the patient (Fig. I and Table 2). The two patients (Cases I and 2) who had an uninterrupted clinical recovery showed normal insulin secretion tests throughout the postoperative period. Case 3 was seriously ill on Day I and at this time she showed a severe suppression of insulin secretion. Her rapid improvement during the succeeding days was accompanied by a rapid return to normal in the insulin secretion test. The clinical state of 
the patient and the facility with which tolbutamide released insulin was closely correlated in the three patients who had a poor postoperative course. The insulin secretion response was nearly completely suppressed in the immediate postoperative period and only returned to normal in parallel with the improvement in their clinical state (Fig. 2). It is of interest to note that in 5 of the 6 patients there was an overshoot in insulin response, as compared with their own preoperative test, at some time during the postoperative course.

\section{Discussion}

These studies show a clear-cut correlation between the clinical state of the patient after open-heart operation, and the ability to secrete insulin in response to the intravenous injection of tolbutamide. The correlation is similar to that reported for the low cardiac output states occurring in patients with cardiogenic shock after myocardial infarction (Taylor et al., 1969; Allison, Chamberlain, and Hinton, 1969) and in severe congestive heart failure (Sharma et al., 1970). The mechanisms responsible for this suppression of insulin secretion are unknown, but a common factor in all of these patients is the low cardiac output.

In the experimental animal a large fall in cardiac output is invariably accompanied by a correspondingly large fall in splanchnic blood flow (Selkurt, Alexander, and Patterson, 1947; Selkurt and Brecher, 1956; Levy, 1958; Gregg, 1962). This fall in splanchnic and presumably pancreatic blood flow may prevent an adequate stimulus reaching the insulinsecreting beta cells. A second possible factor in the suppression of insulin secretion relates to the increased sympathetic drive and raised levels of circulating catecholamines that immediately follow a large fall in cardiac output. The catecholamines, and particularly adrenalin, have been shown not only to cause pathological changes specifically located in the beta cells of the pancreas (Loubatières et al., 1965) but also to suppress insulin both in animals (Kris et al., 1966; Hertelendy et al., 1966; Altszuler et al., 1967) and in man (Porte et al., 1966; Karam et al., 1966; Majid et al., 1970). In patients who develop a low cardiac output state after open-heart surgery, both conditions are present, and together may account for the suppression of insulin release observed.

The therapeutic implications of these findings are worthy of comment. Myocardium damaged by ischaemia depends for its energy production on the metabolism of glucose

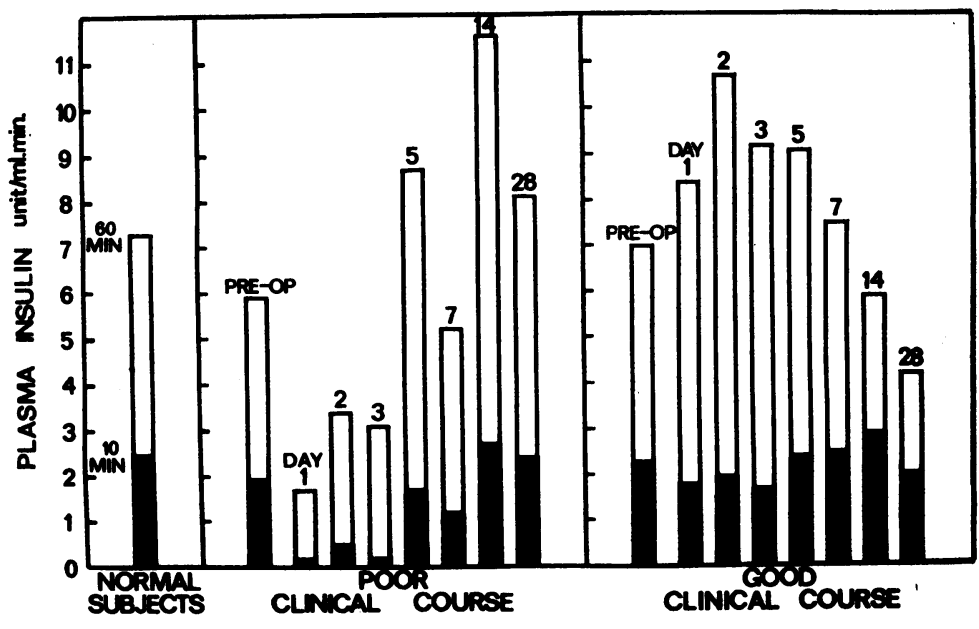

FIG. 2 Average total insulin secretion response to intravenous tolbutamide in 12 normal subjects and 6 patients before and after open-heart operation.

(Owen, Thomas, and Opie, 1969). If such damage is accompanied by loss of ability to secrete insulin, cardiac performance may be further severely impaired. In addition, the correlation between the severity of the circulatory illness and the increase in the free fatty acids observed in the present studies agrees with the earlier findings of Oliver, Kurien, and Greenwood (1968) who showed a correlation between the plasma level of free fatty acids and the incidence of serious dysrhythmias and disorders of conduction after myocardial infarction. In both instances the administration of insulin may possibly produce clinical improvement, and these findings suggest that its use in patients developing the low output syndrome after open-heart operations should be more thoroughly investigated.

The authors wish to thank Mr. G. H. Wooler for allowing them to study his patients; Sisters E. A. Loach and M. Poole for their help and co-operation; Dr. C. J. Hayter, Department of Nuclear Medicine at the General Infirmary, for use of the Philips Counter; Mr. P. Bingham for his assistance with the assays; and Sir Ronald Tunbridge and Professor R. J. Linden for their help and encouragement. The work was assisted by a grant from the Leeds and West Riding Medical Research Trust. P.A.M. holds a Senior Research Fellowship from the Wellcome Foundation and B.C.P. a Senior Research Fellowship from Ciba Laboratories Limited.

\section{References}

Allison, S. P., Chamberlain, M. J., and Hinton, P. (1969). Intravenous glucose tolerance, insulin, glucose, and free fatty acid levels after myocardial infarction. British Medical fournal, 4, 776. 
Altszuler, N., Steele, R., Rathgeb, I., and De Bodo, R. C. (1967). Glucose metabolism and plasma insulin level during epinephrine infusion in the dog. American fournal of Physiology, 212, 677.

Duncombe, W. G. (1963). The colorimetric microdetermination of long-chain fatty acids. Biochemical fournal, 88, 7 .

Fisher, R. A. (1944). Statistical Methods for Research Workers, 9th ed. Oliver and Boyd, Edinburgh.

Gloster, J. A., and Harris, P. (1962). Observations on an enzymic method for the estimation of pyruvate in blood. Clinica Chimica Acta, 7, 206.

Gregg, D. E. (1962). Haemodynamic Factors in Shock: Ciba Foundation Symposium. Ed. by K. D. Bock. Springer, Berlin.

Hales, C. N., and Randle, P. J. (1963). Immunoassay of insulin with insulin-antibody precipitate. Biochemical fournal, 88, 137.

Hertelendy, F., Machlin, L. J., Gordon, R. S., Horino, M., and Kipnis, D. M. (1966). Lipolytic activity and inhibition of insulin release by epinephrinelin the pig. Proceedings of the Society for Experimental Biology and Medicine, 121, 675.

Karam, J. H., Grasso, S. G., Wegienka, L. C., Grodsky, G. M., and Forsham, P. H. (I966). Effect of selected hexoses, of epinephrine and of glucagon on insulin secretion in man. Diabetes, 15, 571 .

Kris, A. O., Miller, R. E., Wherry, F. E., and Mason, J. W. (1966). Inhibition of insulin secretion by infused epinephrine in rhesus monkeys. Endocrinology, 78, 87 .

Laurell, S., and Tibbling, G. (1967). Colorimetric micro-determination of free fatty acids in plasma. Clinica Chimica Acta, 16, 57.

- Levy, M. N. (1958). Influence of levarterenol on portal venous flow in acute hemorrhage. Circulation Research, 6, 587.

Loubatières, A., Mariani, M. M., Chapal, J., Taylor, J., Houareau, M. H., and Rondot, A. M. (1965). Action nocive de l'adrénaline pour la structure histologique des îlots de Langerhans du pancréas.

- Action protectrice de la dihydroergotamine. Diabetologia, 1, 13.

Majid, P. A., Saxton, C., Dykes, J. R. W., Galvin, M. C., and Taylor, S. H. (I970). Autonomic con-

- trol of insulin secretion and the treatment of heart failure. British Medical fournal, 4, 328.
Marbach, E. P., and Weil, M. H. (1967). Rapid enzymatic measurement of blood lactate and pyruvate. Use and significance of metaphosphoric acid as a common precipitant. Clinical Chemistry, 13, 314.

Morley, G., Marks, V., and Dawson, A. (1966). Manual and auto-analyser methods for measuring blood glucose using guaiamcum and glucose oxidase. Proceedings of the Association of Clinical Biochemists, 5, 43.

Oliver, M. F., Kurien, V. A., and Greenwood, T. W. (1968). Relation between serum-free-fatty-acids and arrhythmias and death after acute myocardial infarction. Lancet, $1,710$.

Owen, P., Thomas, M., and Opie, L. (1969). Relative changes in free-fatty-acid and glucose utilisation by ischaemic myocardium after coronary-artery occlusion. Lancet, $\mathrm{I}, \mathrm{I} 187$.

Porte, D., Jr., Graber, A. L., Kuzuya, T., and Williams, R. H. (1966). The effect of epinephrine on immunoreactive insulin levels in man. Fournal of Clinical Investigation, 45, 228.

Saxton, C., Dykes, J. R. W., Majid, P. A., and Taylor, S. H. (1970). The insulin secretion response to intravenous tolbutamide in normal subjects. Clinical Science. In the press.

Selkurt, E. E., Alexander, R. S., and Patterson, M. B. (1947). The rôle of the mesenteric circulation in the irreversibility of hemorrhagic shock. American fournal of Physiology, 149, 732.

-, and Brecher, G. A. (1956). Splanchnic hemodynamics and oxygen utilization during hemorrhagic shock in the dog. Circulation Research, 4, 693.

Seltzer, H. S. (1962). Quantitative effects of glucose, sulfonylureas, salicylate, and indole-3-acetic acid on the secretion of insulin activity into pancreatic venous blood. Fournal of Clinical Investigation, 41, 289.

Sharma, B., Majid, P. A., Pakrashi, B. C., Dykes, J. R. W., and Taylor, S. H. (1970). Insulin secretion in severe heart failure. British Medical fournal, 2, 396.

Taylor, S. H., Saxton, C., Majid, P. A., Dykes, J. R. W., Ghosh, P., and Stoker, J. B. (1969). Insulin secretion following myocardial infarction with particular respect to pathogenesis of cardiogenic shock. Lancet, 2, 1373. 